body'. There is a general feeling that with the formation in India of an increasing number of specialist and local societies, and the resultant increasing tendency of sciences to work in isolation from one another, that a greater measure of co-ordination is required than is afforded by the annual meetings of the Indian Science Congress ; the question of forming an Indian Academy of Sciences is consequently under discussion. One possible solution would be that the Asiatic Society of Bengal should occupy a position analogous to that of the Institute of France and become the parent body for not only an Indian Academy of Sciences, but also for an Indian Academy of Letters to represent the other side of the present activities of the Asiatic Society of Bengal and other groups of men of letters in India. Such a development, with perhaps a reversion of the title of the Society to "Asiatic Society" without the words "of Bengal", so as to remove the provincial sound, would seem to be the simplest solution to the problem and one that would well celebrate the hundred and fiftieth annirersary of the Asiatio Society, should this seem appropriate to the scientific workers of India as a whole. Such a development would also have the great advantage of preserving the liaison that still exists between science and letters in India.

\title{
Economics of Nutrition
}

$\mathrm{T}$ HE Council of the British Medical Association, having realised that the adequate nutrition of the population is a matter of national import. ance, appointed a committee in April 1933 "to determine the minimum weekly expenditure on foodstuffs which must be incurred by families of varying size, if health and working cupacity are to be maintained, and to construct specimen diets". The report of the committee was printed as a supplement to the British Medical Journal of November 25,1933 , which has now been reprinted.

The feature of the pamphlet is a series of sixteen carefully compiled diets suitable in quantity and variety for a single adult man, for children of various ages and families of different sizes. The quantities of the foodstuffs are calculated in accordance with the physiological standards and 'man value' of the families from Cathcart and Murray's figures. A family consisting of a man, a woman, and four children of the ages thirteen, ten, seven and four years, according to this standard has a man value of 4.63 .

Stress is laid upon the kind of protein, whether it is of animal origin (first class), or of vegetable origin (second class). The infant's diet of milk consists of animal protein only, and it is advised that the change from tho infant's to the adult diet be gradual, with the maintenance of a high proportion of animal protein, and be not completed until the child is three to five years of age. The amount of animal protein is maintained at a high level (60-75 per cent of the total protein) at any rate until school age is past, as shown in the specimen diets, and may be continued at this level so long as the child is growing. Unfortunately, the introduction of animal protein adds to the cost of the diet and is not always practicable. It is recom mended that the supply of protein for the child be from cheese, fish and minced meat. We may refer to diet No. 4 proposed for a child of one to two years. It is based upon a minimum of 1 pint of milk daily, which is looked upon as the maximum expenditure which is likely to be possible on this article of food. 'The weekly quantities are : milk 7 pints ; meat $\frac{1}{4} \mathrm{lb}$. ; fish $1 \mathrm{lb}$. ; butter $\frac{1}{8} \mathrm{lb}$. ; flour $1 \mathrm{lb}$.; 'oatmeal 1 lb.; sugar $\frac{1}{8} \mathrm{lb}$.; potatoes $1 \mathrm{lb}$.; $\frac{1}{2} \mathrm{lb}$. each of cabbage, turnips, carrots and tinned tomatoes. In this diet the proportion of animal protein is 71 per cent of the total protein and the calorie value is 1006 ; the child of this age corresponding to a man value of $0 \cdot 3$.

Similar diets with proper first-class protein for older children of three to six years are given in Nos. 5 and 6 . In diets Nos. 7 and 8, for children of six to ten years, the milk is reduced to $\frac{1}{2}$ pint daily.

Diet No. 1 is an example of the bare ration without variety for an adult man and costs 58.25 pence weekly. With variety the cost is increased to 70.5 pence weekly. Diets 9-16 are fumily diets with one or more children of different ages, and the man cost of these diets is $76 \cdot 1-66.5$ pence weekly. The costs have been calculated from a special scale of prices ascertained by the British Medical Association. Another scale of lower prices gives those prevailing in Stockton.

So far as the diets are concerned, the variety and quantities are extraordinarily well chosen and could be universally adopted. We would earnestly recommend all schools and institutions to use these standards of quantities and regard them as the minimum, increasing the quantities of milk, meat, fish and egg if funds permit. Children would thus be given a fair start in life. There is at present a tendency in school diets to restrict the supply of first class protein to a level inconsistent with the demands of growth between the ages of fourteen and eighteen years.

A considerable proportion of the specimen diets consists of dairy produce, vegetables and fruits. The mincrals of the diet are thus amply provided. The supply of vitamins, especially of $A$ and D, and $\mathrm{C}$ is regarded as sufficient from the quantities of milk, butter, eggs, cheese, liver, fish and vegetables. It is pointed out that whole cereals, beans, peas and lentils are the sourco of vitamin B, but some of the dicts do not contain any of these articles of food, and if included the weekly total of such foods is very small. No stress is laid upon the advantage of wholemeal bread in preference to white bread or flour, for the supply of 
the vitamin B group, and in respect of this vitamin the diets cannot be regarded as satisfactory.

A main criticism will always be the costs of the diets, which naturally vary greatly according to season and locality. It is not often that a palatable egg can be purchased for a penny. Cheese at $6 \mathrm{~d}$. per lb. is not everywhere procurable, and minced meat at $6 \mathrm{~d}$. per $\mathrm{lb}$. is not likely to be of good quality, but consist mostly of gristle and fat. Still, the diets show that for a weekly expenditure of 5s.-6s. 6d., a man can procure a well-balanced diet.

The caloric value of these diets is based upon the daily consumption of an adult man, which has been assessed at 3000 . Diet as consumed is not the same as diet as purchased since allowance has to be made for waste, such as bone in meat and fish, outer leaves of vegetables, etc. This waste is commonly reckoned at 10 per cent. The caloric values of the diets is given as 3400 as purchased. This gives a figure of 3060 as consumed. This does not thus vary appreciably from that adopted by the Ministry of Health following a report on dietary investigations of which an account was given in NATURE of June 13, 1931 (vol. 127, page 897). There is no doubt, however, that many families can exist upon a smaller calorie intake, down to 2500 calories, depending upon their manual work.

The allowance of first-class protein of $50 \mathrm{gm}$. a day appears to be a higher allowance than that of the Ministry of Health. The minimum quantity has been assessed at $37 \mathrm{gm}$. a day. The Army ration in peace time contains $62.7 \mathrm{gm}$. of first class protein. There can be no serious objection to taking the mean figure of $50 \mathrm{gm}$. a day, especially when a family including children is taken into consideration.

\section{August Weismann, I834-I9I4}

THE name of August Weismann, the famous professor of zoology in the University of Freiburg-im-Breisgau, the centenary of whose birth falls on January 17, will always be remembered as that of one who exercised a profound influence on the progress of biological doctrine and speculation. As a teacher of zoology Weismann achieved a far-reaching reputation; and by the students who worked under his direction, among whom, it may be remembered, was the late Prof. Gilbert Bourne of Oxford, his instruction was estimated at the highest value. But it was as an investigator and explorer of the methods of evolution that his influence was most widely felt, especially perhaps in Great Britain.

It was Weismann who first detected the true significance in the development of the insect wing of the rudimentary larval structures noticed by previous observers. His work on the embryology of the Diptera, and especially of Corethra, led him to the recognition of the origin of the appendages of the adult insect in hypodermic downgrowths to which he gave the name of Imaginalscheiben (imaginal discs or folds). Linked with this came his discovery of the remarkable phenomenon of histolysis, which he supposed to be of more general occurrence than later observations have shown to be the case. The importance of Weismann's work in this department was early recognised by Darwin, who contributed a prefatory notice to the "Studies in the Theory of Descent". This was the book through which, owing to the good offices of Prof. Meldola, Weismann's biological theories were chiefly brought to the notice of men of science in Great Britain. To the "Studies" may be attributed the impulse which started Prof. E. B. Poulton on many of those lines of investigation which have led in his hands to such fruitful results.

The outstanding claim of Weismann to the attention of biologists, however, was his bold challenging of the supposed effect of Lamarckian factors in heredity. This view, at the time of its publication, was no less than revolutionary. The opposition that it aroused, at first strong and sustained, has never completely died down; at the present day, however, the votaries of Lamarckism are comparatively few in number. To this result the developments of Mendelism have contributed in no small degree, but the first effective attack on the transmission of somatic modifications was delivered by Weismann. His elaborate scheme of 'biophors', 'determinants' and 'ids' has not stood the test of later investigation; there is no doubt, however, that his postulate of 'determinants' foreshadows in many respects the present-day conception of 'genes'. Moreover, in his theory of intra-germinal selection, by which he sought to reconcile the old antagonism of preformation and epigenesis, he may be said to have anticipated in some measure the modern doctrine of the interaction of genetic factors in ontogeny.

Weismann was led in course of time to modify to some extent the somewhat exaggerated view that he took of the inaccessibility of the germ. plasm; but the distinction now generally drawn between the genotype and the phenotype is evidence of the virtual stability of the position first definitely established by him. It would be interesting to know, were it possible, what his attitude would be in face of the developments that have followed on Mendel's discovery of the segregation of the gametes.

Weismann, with his tall figure and pleasant demeanour, was a striking and attractive personality. He was not averse from discussing the relations between science and philosophy, though he was fully aware of the limitations that exist on both sides. His general position may be briefly summarised in his own words, translated by Meldola as follows: "The mechanical conception of Nature very well admits of being united with a teleological conception of the Universe." F. A. D. 